\title{
Z POMOCA CZŁOWIEKOWI GRZESZNEMU, CZYLI O MIŁOSIERNYM TOWARZYSZENIU KOŚCIOŁA
}

DOI: http://dx.doi.org/10.12775/TiCz.2021.033

Streszczenie. Człowiek został stworzony przez Boga na Jego obraz i podobieństwo. Jednak na skutek grzechu pierwszych rodziców skażona została ludzka natura. Grzech wprowadził nieład w ludzkie życie i oddalił człowieka od Boga. Bóg jednak nie zrezygnował z niego. Z pomocą grzesznej ludzkości przyszedł Boży Syn, który dokonał dzieła odkupienia poprzez ofiarę złożoną na drzewie krzyża. Z tej ofiary płynie zbawcza moc i siła. Jednak człowiek w swej wolności ma możliwość decydowania o swoim szczęściu i opowiadania się po stronie dobra bądź zła. Okazuje się, że człowiek w swej egzystencji ulega ciągle pokusie i popełnia grzech, oddalając się tym samym od Bożej miłości. Bóg jednak nadal przychodzi mu z pomocą, a czyni to we wspólnocie Kościoła, który powołany jest do głoszenia prawdy i urzeczywistniania Bożego miłosierdziu. Tak więc człowiek grzeszny może ciągle liczyć na Bożą pomoc. Ta pomoc przychodzi do niego w słowie Bożym i w sakramentach świętych, a także poprzez miłosierne towarzyszenie Kościoła. Jednak Bóg do niczego nikogo nie zmusza, stąd też decyzja o odrzuceniu grzechu należy do człowieka.

Słowa kluczowe: godność człowieka, grzech, grzesznik, miłosierdzie Boga, towarzyszenie, formy niesienia pomocy, sakramenty, Eucharystia, sakrament pokuty i pojednania, spotkanie, rozmowa.

Abstract. Aiding the Sinful Man: About the Merciful Accompaniment by the Church. Man was created by God in His image and likeness. However, as a result of the 
sin of our first parents, human nature became tainted. The sin disrupted people's lives and pushed people away from God. However, God did not give up on man. The Son of God came with His aid to the sinful mankind, accomplishing the work of redemption through the sacrifice made on the tree of the cross. From this sacrifice comes salvific power and strength. However, man in his freedom has the opportunity to decide about his happiness and about taking the side of good or evil. It turns out that man in his existence succumbs to temptation and commits sins, thereby distancing himself from God's love. Nevertheless, God still comes to his aid and does so in the community of the Church, which is called upon to proclaim the truth and to fulfill God's mercy. So, a sinful person can still count on God's aid. This aid comes to him in the Word of God and in the Holy Sacraments as well as through the merciful accompaniment of the Church. However, God does not force anyone to do anything, therefore it is up to the sinful person to decide to reject sin. The article presents the issues outlined above in a synthetic way, introducing selected forms of pastoral accompaniment of the Church to a person entangled in the reality of $\sin$.

Keywords: human dignity, sin, sinner, God's mercy, accompaniment, forms of aid, sacraments, the Eucharist, the sacrament of penance and reconciliation, meeting, conversation.

W bulli o nadzwyczajnym jubileuszu miłosierdzia Misercordiae vultus papież Franciszek skierował gorący apel do wiernych Kościoła: „O jakże pragnę, aby nadchodzące lata były naznaczone miłosierdziem tak, byśmy wyszli na spotkanie każdej osoby, niosąc dobroć i czułość Boga! Do wszystkich, tak wierzących, jak i tych, którzy są daleko, niech dotrze balsam miłosierdzia jako znak Królestwa Bożego, które jest już obecne pośród nas" (MV 5). Adresatami tego apelu powinni stać się w pierwszej kolejności duszpasterze, gdyż to oni mogą poranionym na różne sposoby ludziom obecnych czasów nieść balsam miłosierdzia. Mogą to czynić przez głoszenie miłosierdzia Bożego, przez sprawowanie sakramentów świętych zwłaszcza sakramentu Eucharystii oraz pokuty i pojednania, a także namaszczenia chorych, jak również poprzez różne formy wspierania, a przede wszystkim przez przeniknięty miłosierdziem styl życia i posługiwania duszpasterskiego. Jednak zaznaczyć należy, że owo zadanie niesienia pastoralnej pomocy spoczywa na wszystkich członkach wspólnoty Kościoła. Niniejsza publikacja składająca się z czterech komplementarnych części przybliża Czytelnikom fundamentalną prawdę o ludzkiej godności i rzeczywistości grzechu obecnej w życiu osoby wierzącej, tajemnicy 
Bożej miłości i miłosierdzia, wskazuje na niezwykle aktualną w praktyce pastoralnej zasadę miłosiernego towarzyszenia i wreszcie prezentuje pastoralne formy niesienia pomocy przez wspólnotę Kościoła osobom zmagającym się w walce $\mathrm{z}$ grzechem.

\section{AFIRMACJA CZłOWIEKA A DOŚWIADCZENIE GRZECHU}

Człowiek jest umiłowanym stworzeniem Boga, ukształtowanym na obraz i podobieństwo Stwórcy. Tylko człowiek może dostąpić osobowego zjednoczenia z Trójjedynym Bogiem, zyskując przez to „pewnego rodzaju nieskończoność”'. Człowiek, dzięki duchowej naturze i zdolności poznania umysłowego, a także dzięki wolności wyboru i działania, pozostaje od początku w szczególnej relacji do Boga. Poznaje on Boga i jednocześnie łączy się z Nim. Posiada zdolność nawiązania kontaktu ze swoim Stwórcą. Św. Jan Paweł II wyjaśniał, że człowiek zdolny jest, jako jedyne stworzenie, do partnerskiego dialogu z Bogiem i bezpośredniej z Nim komunii².

Szczególnym znakiem obrazu Boga w życiu ludzkim jest wolność. Bez wolności osoba ludzka pozbawiona byłaby samodzielności w kształtowaniu siebie samej oraz w wyborze uzasadnień i wartości. Wolność stanowi integralny element osobowej struktury człowieka i najbardziej uzewnętrznia się poprzez czyny. Istota wolności tkwi we wnętrzu człowieka. Wolność jest darem i zadaniem, który sprawia, że człowiek może kształtować oblicze świata, tworzyć wspaniałe dzieła i nadawać im niepowtarzalny kształt (por. VS 86-87).

Stworzony przez Boga i na Jego obraz człowiek posiada również zdolność autopoznawania, doświadczania własnego bytu w świecie, stwierdzania swojej odrębności i zależności w istnieniu od Stwórcy. Obdarzony jest on możliwością wyboru i samostanowienia, dlatego nie utożsamia się z widzialnym światem istot żyjących a pośród przedmiotów i rzeczy jest on jedynym podmiotem zdolnym do refleksji nad samym sobą i światem. Pragnienie rozpoznania własnego bytu i natury świata jest wewnętrzną po-

1 Jan Paweł II, Przemówienie podczas audiencji generalnej (5.05.1986), OsRomPol 7 (1986) 3, s. 10.

2 Tenże, Przemówienie do uczestników Międzynarodowego Kongresu Teologii Moralnej (10.04.1986), OsRomPol 7 (1986) 5, s. 10. 
trzebą istoty ludzkiej, która zwrócona jest ku prawdzie i przeznaczona jest do nieśmiertelności (CA 53).

Jednak wskutek grzechu pierwszych rodziców skażeniu uległa ludzka natura. Została ona zraniona w swoich naturalnych siłach, poddana niewiedzy, cierpieniu i władzy śmierci oraz skłonności do grzechu. Zaznaczyć należy, że w dziejach ludzkości prawdziwą katastrofą był grzech pierworodny, gdyż sprowadził on na ludzi konkretne skutki. Człowiek, który przed grzechem był w relacji do Pana Boga, po grzechu został wypędzony z raju na poniewierkę. Tak więc grzech zerwał przyjaźń człowieka z Bogiem oraz wprowadził nieład w jego życie, dotknął człowieka i podstawowej wspólnoty jego egzystencji (zob. KKK 405).

Niezaprzeczalną jednak prawdą jest, że nawet grzech nie jest w stanie zniszczyć obrazu Bożego w człowieku. Grzech jest nieposłuszeństwem wobec prawa Bożego i sięga głęboko w jego strukturę bytową (RP 14-16), to jednak człowiek w istocie samej nosi w sobie odblask Bożej mocy. Pomimo istniejącego w nim zarzewia grzechu, podążać ma on w kierunku prawdy, dobra i piękna. Jest to możliwe dzięki pomocy Ducha Świętego, którego mieszkaniem stało się ciało ludzkie przez dzieło odkupienia Chrystusa ${ }^{3}$. Po swoim upadku człowiek nie został opuszczony przez Boga. Przeciwnie Bóg wzywa go i zapowiada mu tajemnicze zwycięstwo nad złem oraz podniesienie z upadku (KKK 410). To zaś urzeczywistnia się poprzez ofiarę jaką Jezus złożył na drzewie krzyża, dokonując dzieła odkupienia. Ratunkiem są także sakramenty święte ustanowione przez Jezusa i pozostawione Kościołowi. Szczególną rolę odgrywa sakrament chrztu świętego, który gładzi pierworodny grzech i na nowo kieruje do Boga. Jednak konsekwencje grzechu dla osłabionej i skłonnej do zła natury pozostają i wzywają człowieka do podejmowania ciągłej walki duchowej.

Tymczasem codzienne życie pokazuje, że współczesny człowiek bardzo często nie przyznaje się do swojego grzechu i słabości. Stąd też św. Jan Paweł II zauważa, że obecne czasy charakteryzuje „dziwne poczucie zaniku grzechu”, a najgroźniejszym zjawiskiem jest zanik poczucia Boga, który prowadzi w konsekwencji do zaniku poczucia grzechu w życiu ludzi wierzących. „Współczesnemu człowiekowi przychodzi trudniej niż kiedykolwiek uznanie własnych błędów i decyzja zawrócenia z drogi, aby po

3 Tenże, Przemówienie podczas audiencji generalnej (9.04.1986), OsRomPol 7 (1986) 4, s. 19. 
naprawieniu błędów podjąć wędrówkę na nowo; dzisiejszy człowiek bardzo niechętnie mówi: żałuję czy przykro mi; wydaje się, że instynktownie, a często bardzo stanowczo odrzuca to wszystko, co jest pokutą w sensie ofiary przyjętej i praktykowanej dla naprawienia grzechu” (RP 26).

Opisana przez Papieża sytuacja pokazuje, że również sumienia ludzkie „jakby stępiły się" i dlatego nie odróżniają dobra od zła. Wielu chrześcijan nie wie lub zwyczajnie nie chce wiedzieć, czym jest grzech, jakby ta wiedza miała odebrać im wolność ${ }^{4}$ W istocie jednak każdy grzech narusza fundamentalną dla życia ludzkiego relację z Bogiem, jest niewiernością wobec przymierza, które Bóg zawarł z człowiekiem. Jest wreszcie odrzuceniem prawdy o tym kim jest człowiek ${ }^{5}$.

Każdy chrześcijanin powinien uznać za prawdę fakt, że grzech istnieje, ale również i to, że istnieje w nim. Zafałszowane poczucie grzechu albo utrata tego poczucia, prowadzi do zakwestionowania fundamentalnych prawd wiary (por. RP 19). Grzech narusza w człowieku porządek etyczny i pociąga za sobą konsekwencje natury psychicznej, somatycznej i społecznej. Zanegowanie grzechu nieuchronnie prowadzi do negacji Boga (zob. VS 32) .

Dlatego w adhortacji apostolskiej Ecclesia in Europa papież Jan Paweł II wyjaśniał, że wielu ludzi współczesnych żyje tak jakby Bóg nie istniał i że nie potrafią oni uznać się za grzeszników a tym samym prosić Boga o przebaczenie. Taka postawa wyraża się rezygnacją z przystępowania do sakramentu pojednania. Stąd w tej sytuacji szczególnego znaczenia nabiera zachęta i przypomnienie o znaczeniu sakramentu pokuty i pojednania, którego „formą [...] jest osobiste wyznanie grzechów, po którym następuje indywidualne rozgrzeszenie" (EiE 76). Sam zaś sakrament pokuty jest spotkaniem z Jezusem przebaczającym ludzkie grzechy i pomaga on człowiekowi kroczyć drogą Ewangelii i czynić dobro?

4 Tenże, Homilia podczas Mszy św. (San Salwador, 8.02.1996), OsRomPol 17 (1996) 5, s. 27.

5 Tamże.

${ }^{6}$ Jan Paweł II, Przemówienie na spotkaniu z Konferencją Episkopatu Austrii (Salzburg, 24.06.1988), OsRomPol 9 (1988) 7, s. 25; tenże, Przemówienie podczas audiencji generalnej (1.03.1983), OsRomPol 4 (1983) 3, s. 18.

7 Benedykt XVI, Przemówienie do uczestników kursu dla spowiedników (9.03.2012), w: https://opoka.org.pl/biblioteka/W/WP/benedykt_xvi/przemowienia/spowiednicy_09032012.html (data dostępu: 20.08.2021). 
Papież Benedykt XVI spowiedź nazwał „sakramentalną siłą nowej ewangelizacji”, wskazując, że: „Nowa ewangelizacja rozpoczyna się [...] od konfesjonału", a w jednym z wygłoszonych przemówień wskazywał na rozszerzające się zjawisko sekularyzacji społeczeństw o długiej tradycji chrześcijańskiej, czego wyraźnym znakiem jest spadek praktyk religijnych. Podkreślał przy tym, że zjawisko to widoczne jest w uczestnictwie w liturgii eucharystycznej, a jeszcze bardziej w korzystaniu z sakramentu pokuty 9 .

Sytuację moralną współczesnego świata przedstawioną w dokumentach Kościoła potwierdzają bardzo wyraźnie liczne badania empiryczne prowadzone w różnych ośrodkach naukowych. Przeprowadzone badania m.in. przez Instytut Statystyki Kościoła katolickiego pod kierunkiem ks. prof. J. Mariańskiego w 2013 roku pokazują, że wskaźnik paschantes w Polsce wynosił w roku 2002 - 82,1\%, a w 2012 roku - 76,9\%. Wskaźnik ten uzyskano w wyniku zestawienia odpowiedzi udzielonych przez respondentów na postawione w kwestionariuszu pytanie: jak często przystępuje Pan(i) do spowiedzi? Odpowiadający mógł wybrać jedną z zaproponowanych odpowiedzi: dwa razy w miesiącu; raz w miesiącu; kilka razy w roku; raz w roku. Ksiądz prof. Mariański stwierdził, że uzyskane deklaracje badanych o ich zaangażowaniu w praktykę sakramentu pojednania są nieco zawyżone w stosunku do zachowań rzeczywistych i prawdopodobnie obiektywny wskaźnik paschantes kształtuje się w granicach $60 \%$, wskazując tym samym, że katolicy w wysokim procencie nie przystępują do sakramentu pokuty i pojednania oraz że nie podejmują walki ze swoimi słabościami i grzechem ${ }^{10}$.

Natomiast badania przeprowadzone przez doktoranta Katedry Teologii Praktycznej UMK w 2018 roku wśród młodzieży maturalnej archidiecezji przemyskiej pokazały, że świadomość ludzkich słabości i grzechów deklaruje ponad $83 \%$ badanych. Natomiast tylko $11 \%$ przystępuje do spowiedzi raz w miesiącu, $27 \%$ badanych zadeklarowało, że spowiada

8 Tamże.

9 Benedykt XVI, Przemówienie do uczestników Zgromadzenia Ogólnego Konferencji Episkopatu Włoch (24.05.2012), w: https://opoka.org.pl/biblioteka/W/WP/benedykt_ xvi/przemowienia/ep-it_24052012.html (data dostępu: 20.05.2021).

10 J. Mariański, Praktyki religijne w Polsce $w$ procesie przemian, w: Postawy społeczno-religijne Polaków 1991-2012, red. L. Adamczuk E. Firlit, W. Zdaniewicz, Warszawa 2013, s. 59-101. 
się mniej lub bardziej regularnie. Blisko $60 \%$ zadeklarowało, że nie spowiada się regularnie, albo wręcz nie spowiada się wcale ${ }^{11}$.

Przeprowadzone badania wśród wierzących Polaków pokazują, że katolicy przystępują do sakramentu pokuty i pojednania nieregularnie, około dwa razy w roku najczęściej przy okazji najważniejszych świąt. $\mathrm{Na}$ podstawie przywołanych badań można zauważyć odchodzenie od praktyki spowiedzi także tej wielkanocnej oraz należy stwierdzić, że mamy w Kościele do czynienia z kryzysem sakramentu pokuty i pojednania oraz z zobojętnieniem ludzkich sumień na rzeczywistość grzechu.

\section{TAJEMNICA MIŁOSIERDZIA BOGA}

Człowiekowi współczesnemu należy przypominać i głosić prawdę o miłosierdziu Boga, gdyż prawda o Bogu, będącym Miłością, stanowi punkt kulminacyjny wszystkiego, co zostało objawione przez proroków a ostatecznie zrealizowane poprzez dzieło odkupienia Syna Bożego ${ }^{12}$. Bóg stworzył świat, ponieważ jest wszechmocny, a wszechmocą Jego kieruje Mądrość i Miłość. Prawda ta rozświetla rzeczywistość stworzenia objawioną przez Boga. Najbardziej o Bożej Miłości świadczy dzieło odkupienia, którego Ojciec dokonał w swoim Synu Jezusie Chrystusie. Tylko Miłość potrafi stworzyć świat z nicości, wyprowadzić dobro ze zła oraz nowe życie z grzechu i śmierci ${ }^{13}$.

Wczytując się w nauczanie obecnego papieża Franciszka odkrywamy, że centralne miejsce zajmuje w nim prawda o miłosierdziu Boga. W bulli ogłaszającej Rok Miłosierdzia Misericordiae vultus papież pisze: „miłosierdzie: to jest słowo, które objawia Przenajświętszą Trójcę. Miłosierdzie: to najwyższy i ostateczny akt, w którym Bóg wychodzi nam na spotkanie. [...] Miłosierdzie: to droga, która łączy Boga z człowiekiem,

${ }^{11}$ M. Flader, Formacja chrześcijańska młodzieży w mediach społecznościowych. Studium teologicznopastoralne na podstawie badań maturzystów $w$ archidiecezji przemyskiej, praca doktorska (archiwum mps UMK) Toruń 2020.

12 A. Nossol, Teologia bliższa życia, Opole 1984, s. 34.

13 Jan Paweł II, Przemówienie podczas audiencji generalnej (2.10.1985), OsRomPol 6 (1985) 10-12, s. 19; zob. J. Kudasiewicz, Miłosierdzie w Ewangeliach, w: Jan Paweł II. Dives in Misericordia. Tekst i komentarze, red. S. Nagy, Lublin 1983, s. 69; W. Pikor, Biblijne pytania o Boże Miłosierdzie, Pelplin 2016. 
ponieważ otwiera serce na nadzieję bycia kochanym na zawsze, pomimo ograniczeń grzechu” (MV 2). Papież Franciszek wyjaśnia, że miłosierdzie to nie tyle przymiot, ile raczej imię Boga, istota Jego natury. Tezę tę uzasadnia licznymi cytatami ze Starego Testamentu, szczególnie z księgi Psalmów. Psalmy pokazują, że Bóg jest przede wszystkim cierpliwy i miłosierny, a widać to po Jego działaniu w historii. Papież konstatuje, że „miłosierdzie Boga nie jest jakąś abstrakcyjną ideą, ale jest konkretnym faktem, dzięki któremu On objawia swoją miłość ojcowską i matczyną, która wypływa z wnętrzności i zwraca się do syna” (MV 6).

Miłosierdzie jest więc „siłą, która zwycięża wszystko, która wypełnia serce miłością i pociesza przebaczeniem” (MV 6). Ta siła i moc umożliwiają zatem prawidłowy rozwój życia chrześcijańskiego, który jest kontynuowany i uobecniany we wspólnocie Kościoła. Kościół bowiem stworzony $\mathrm{z}$ inicjatywy Boga jest powołany do pośrednictwa w przekazywaniu Bożego życia i miłości ludziom wszystkich czasów. Przez głoszenie słowa Bożego oraz sprawowanie sakramentów świętych Kościół rodzi i wychowuje swoich wyznawców do życia miłością na co dzień. Prowadzi do pełni uczestnictwa w wiekuistej chwale Boga. Kościół nie może przestać być miłosierny, gdyż z ustanowienia Bożego jest on sakramentem Bożego miłosierdzia oraz podstawową drogą doświadczenia odwiecznej miłości. Powołany do istnienia Kościół naśladuje Jezusa i urzeczywistnia Jego zbawcze dzieło. W swojej misji objawia ludziom Bożą miłość poprzez duszpasterstwo ukierunkowane na wypełnianie przykazania miłości Boga i bliźniego w prostocie i pokorze ${ }^{14}$.

Współczesne nauczanie Kościoła wyjaśnia, że miłosierdzie Boga odnosi się do moralnej, jak i materialnej kondycji człowieka a jednocześnie jest ono lekarstwem na osłabioną grzechem jego kondycję. Dar miłosierdzia ofiarowany jest człowiekowi szczególnie w sakramencie pokuty i pojednania. Stąd też kolejni papieże zachęcali do korzystania z tegoż sakramentu, gdyż grzeszny człowiek dotyka w nim miłosierdzia Bożego, a sakrament ten jest dla niego źródłem nawrócenia i prawdziwego pokoju wewnętrznego. Papież Franciszek jednoznacznie podkreślał, że: „Bóg ni-

${ }_{14}$ Zob. S. Mojek, Kościót jako sakrament we wspólnocie ludzkiej, „Roczniki Teologiczne" 40 (1993) 3, s. 13-14. 
gdy nie męczy się odpuszczaniem grzechów" i przy każdej okazji wskazywał, jak bardzo ceni postawę miłosierdzia w posłudze duszpasterskiej ${ }^{15}$.

\section{ASTORALNA ZASADA TOWARZYSZENIA CZłOWIEKOWl}

Zadaniem Kościoła jest urzeczywistnianie zbawczego planu Boga poprzez głoszenie i realizowanie miłosierdzia Boga. Dzieło to dokonuje się między innymi poprzez towarzyszenie na drodze wiary. Towarzyszenie oznacza bycie z kimś, pozostawanie i asystowanie drugiemu człowiekowi. Polega ono na byciu we wszystkich ludzkich doświadczeniach, zwłaszcza dotkliwych i nierzadko długotrwałych. Termin towarzyszenie w nauczaniu Kościoła oznacza troskę o człowieka, o jego życie i zbawienie (EG 24). Wszyscy zatem wierni, jak i pasterze mają za zadanie towarzyszyć „swoim braciom w wierze lub na drodze otwierania się na Boga” (EG 44). Mają oni z miłosierdziem i cierpliwością towarzyszyć możliwym etapom rozwoju ludzi będących w drodze. Papież Franciszek wskazuje, że do wszystkich potrzebujących powinna dotrzeć pociecha oraz impuls zbawczej miłości Boga, niezależnie od ułomności i upadków człowieka. Stąd też Kościół zachęca, aby wychodzić do ludzi, docierając zwłaszcza do tych znajdujących się na wszelkich „ludzkich peryferiach”. Nauczanie współczesne Kościoła w osobie papieża Franciszka zachęca, aby ze spokojem „spojrzeć w oczy i wysłuchać, aby towarzyszyć człowiekowi, który pozostał na skraju drogi” tak, żeby ów „człowiek poszukujący pomocy mógł zawsze przyjść po pomoc”. Stąd też „Kościół jest jak ojciec syna marnotrawnego, który pozostawia drzwi otwarte, aby mógł on wejść bez trudności, kiedy powróci” (EG 46).

Duszpasterska zasada towarzyszenia dotyczy wszystkich wiernych. Dlatego w adhortacji Evangelii gaudium mowa jest o formacji członków Kościoła, czyli kapłanów, zakonników i świeckich do „sztuki towarzyszenia” (EG 169). Podkreślenie potrzeby formacji wskazuje jak bardzo waż-

${ }^{15}$ Franciszek, Przemówienie podczas spotkania z kapłanami diecezji rzymskiej (6.03.2014), w: https://opoka.org.pl/biblioteka/W/WP/franciszek_i/przemowienia/ kaplani_06032014.html (data dostępu: 21.08.2021); zob. EG; A. Draguła, O szpitalu polowym papieża Franciszka, w: https://wiez.pl/2015/10/30/o-szpitalu-polowym-papieza-franciszka/ (data dostępu: 21.08.2021). 
na i potrzebna jest owa misja towarzyszenia współczesnemu człowiekowi jakże często zagubionemu i wołającemu o pomoc. Stąd też oczywistością jest, że jeżeli człowiek nie znajdzie zrozumienia i pomocy w Kościele, będzie jej szukać gdzie indziej, jak chociażby w sektach, które prowadzą do degradacji osoby i odciągają go od wiary. Towarzyszyć w drodze to znaczy być z ludźmi, a nie tylko wskazywać i pouczać ${ }^{16}$. Ludzie wierzący a zwłaszcza ci, którzy się pogubili potrzebują w swoim życiu duchowych przyjaciół, którzy są zawsze gotowi ofiarować im swój czas, odczytać ich problemy i podążać z nimi. Towarzyszenie w podejmowaniu nawrócenia i dojrzewaniu wiary, a także w odkrywaniu Boga to po prostu delikatna obecność. Nawet jeżeli na początku towarzyszenia ktoś jest niechętny do nawiązania relacji, to jednak cierpliwa asystencja, modlitwa i rozmowa przynoszą pomoc i ulgę. Towarzyszenie ma dwa wymiary: zewnętrzny, gdyż jest wędrowaniem z ludźmi przez ich życie i odkrywaniem z nimi Chrystusa oraz wewnętrzny, który jest prowadzeniem człowieka w głąb siebie, tak aby ten odkrył w sobie swojego Stworzyciela, Zbawiciela i Przyjaciela. Papież Franciszek wskazuje na znaczenie towarzyszenia duchowego, które powinno coraz bardziej prowadzić do Boga (EG 170). Ten rodzaj towarzyszenia nabiera na aktualności zwłaszcza dzisiaj w cywilizacji zranionej anonimowością a jednocześnie obsesyjnej na punkcie szczegółów życia innych (EG 169).

W procesie towarzyszenia istotną rolę odgrywają osoby pragnące nieść pomoc drugiemu człowiekowi. Stąd dobrze jest gdy osoby te odznaczają się głęboką wiarą, pobożnością i swoim życiem dają świadectwo wiary, gdyż ono najbardziej przemawia zwłaszcza zaś do człowieka poszukującego, mającego wątpliwości w wierze czy błądzącego (zob. EN 150). Kontakt z osobą wierzącą i praktykującą pozwala doświadczyć miłości Boga i odkryć własne powołanie i miejsce w świecie oraz w Kościele. Kontakt osobowy ma szczególne znaczenie, gdyż już sam fakt zatrzymania się i poświęcenia czasu drugiemu stanowi cenny gest i jest dobrym punktem wyjścia, aby najpierw na płaszczyźnie ludzkiej, a następnie nadprzyrodzonej wnieść światło Ewangelii w życie poszukującego. Wzorem osoby towarzyszącej jest Chrystus, który z miłością spoglądał na każdego, a zwłaszcza pytającego młodzieńca o to, jak żyć, by osiągnąć życie wieczne (Mk 10,17-22).

16 Zob. K. Pawlina, Polska młodzież przełomu wieków, Warszawa 1998, s. 196. 
Osoby zaangażowane $\mathrm{w}$ proces towarzyszenia powinny odznaczać się przede wszystkim dojrzałą osobowością ${ }^{17}$. Papież Franciszek szczególnie wskazuje na cnotę cierpliwości zwłaszcza podczas słuchania drugiego człowieka, zrozumienia jego niepokojów i komunikatywność języka (EG 105). Zaznacza przy tym, że w komunikacji z drugim pierwszą sprawą jest „zdolność serca”, umożliwiająca bliskość, bez której nie ma prawdziwego spotkania duchowego. „Jedynie wychodząc od słuchania pełnego szacunku i zdolnego do współczucia, można znaleźć drogi do autentycznego rozwoju, można rozbudzić pragnienie ideału chrześcijańskiego, gorącą chęć, by odpowiedzieć w pełni na miłość Bożą i pragnienie rozwijania tego, co Bóg zasiał w naszym życiu” (EG 171) ${ }^{18}$.

Zaznaczyć należy, że proces towarzyszenia drugiemu człowiekowi może przebiegać w wielu miejscach. Takimi miejscami są świątynie, kancelarie, domy parafialne, poradnie rodzinne, szkoły a także środowisko rodzinne. Jednak miejscem wyjątkowym jest spotkanie $\mathrm{z}$ drugim człowiekiem w przestrzeni liturgicznej zwłaszcza podczas sprawowania sakramentów świętych szczególnie sakramentu Eucharystii oraz pokuty i pojednania.

\section{WYBRANE FORMY NIESIENIA POMOCY CZŁOWIEKOWI GRZESZNEMU}

Pomoc człowiekowi grzesznemu dokonuje się poprzez szereg form, do których zaliczyć trzeba przede wszystkim uzdrawiającą rolę słowa Bożego, przypominającego fundamentalną prawdę o miłosierdziu Boga, sakramenty święte, a zwłaszcza sakrament Eucharystii oraz pokuty i po-

17 Do podstawowych cech mających wpływ na efektywność towarzyszenia zaliczyć należy: kongruencję, a więc ukazywanie siebie i przekazywanie innym swoich doświadczeń w sposób jasny, bez pozy i maski; autentyzm, gdyż wyzwala on u rozmówcy poczucie zaufania i bezpieczeństwa, prowadząc do odrzucenia mechanizmów obronnych; pozytywne nastawienie; zdolność do empatii (wejście w świat przeżyć drugiego człowieka); cierpliwość i uwagę w słuchaniu, szacunek i życzliwość; unikanie postaw autorytatywnych i moralizatorskich, a także poszanowanie wolności. A. Tomkiewicz, Rozmowa pastoralna, w: Leksykon teologii pastoralnej, red. R. Kamiński, W. Przygoda, M. Fiałkowski, Lublin 2006, s. 750.

18 Zob. Franciszek, Bóg jest młody. Rozmowa $z$ Thomasem Leoncinim, Kraków 2018, s. 37-39. 
jednania, modlitwę wstawienniczą, świadectwo życia osób wierzących, braterskie spotkania oraz rozmowę pastoralną. Wszystkie te formy wpisane są w pastoralne towarzyszenie Kościoła człowiekowi pragnącemu dzień po dniu pogłębiać swoją relację z Bogiem, a zwłaszcza podźwignąć się z upadku.

W procesie zrozumienia tajemnicy Bożego Miłosierdzia i uświadomieniu skutków, jakie powoduje grzech w życiu człowieka, a jednocześnie $\mathrm{w}$ zrozumieniu istoty prawdziwego nawrócenia ze szczególną pomocą grzesznikowi przychodzi słowo Boże. Dlatego człowiek wierzący powinien w nie się uważnie wsłuchiwać i nim kierować w swojej codzienności. Sobór Watykański II, zachęcając do korzystania ze słowa Bożego, wyjaśnia, że tkwi w nim niewyobrażalna moc. Stąd też oświetla ono podstawowe wydarzenia z życia chrześcijańskiego (KO 21; 25). Bóg poprzez Słowo wychodzi do człowieka ze swoją zbawczą miłością i działaniem, które dostępne są zwłaszcza w przestrzeni liturgicznej. Słowo Boże przyjęte z wiarą umacnia i kształtuje człowieka, jego życie, tworzy w duszy Królestwo Boże i obdarza wewnętrzną i tajemniczą mocą (Rz 1,16).

Zauważyć należy, że w pewnym stopniu słowo Boże jest dla człowieka obroną zwłaszcza w momentach pokusy, gdyż im bardziej przenika ono jego osobę, tym bardziej treść Słowa wnika w ludzką pamięć i serce, przybliżając do Boga i dobrych czynów. Tak więc słowo Boże przychodzi penitentowi z pomocą w procesie przywracania poczucia grzechu, ale ono również przypomina o Bożym Miłosierdziu i nieogarnionej miłości. Teksty biblijne mówią bardzo wyraźnie o tym, jak Jezus przebaczał grzechy i wzywał do przemiany życia, jak władzę odpuszczania grzechów przekazał Kościołowi i motywuje do kroczenia drogą świętości. Dlatego też słowo Boże powinno stawać się częścią myślenia człowieka wierzącego a przede wszystkim winno być dla niego drogowskazem w dokonywaniu życiowych wyborów ${ }^{19}$.

Również sakramenty święte łączą człowieka z Chrystusem, przez co umożliwiają mu udział w życiu Bożym. Są one mocą, która wychodzi z Ciała Chrystusa (zob. Mk 5,25-34), aby uleczyć człowieka z ran grzechu i dać mu nowe życie (KKK 1116). Sakramenty łączą człowieka wierzącego z dziełem odkupienia. Są objawieniem samego Chrystusa, gdyż poprzez

19 G. Strzelczyk, Kościół niełatwa miłość, Kraków 2017, s. 78-79. 
nie wchodzi się w życiodajne z Nim zjednoczenie. Działanie sakramentów należy ujmować personalistyczne jako znaki spotkania międzyosobowego, jako spotkanie stale żyjącego uwielbionego Chrystusa $\mathrm{z}$ wierzącym człowiekiem, osobą rozumną i wolną, a zatem zobowiązaną do aktów świadomych ${ }^{20}$.

Sakramentem, w którym najpełniej wyraża się nowy wymiar życia w Chrystusie, jest Eucharystia, gdyż to ona prowadzi do spotkania i zjednoczenia. Przez Eucharystię, człowiek wierzący wraz ze wspólnotą Kościoła uczestniczy w śmierci i zmartwychwstaniu Chrystusa. Mocą działania tego sakramentu i mocą zbawczej męki Jezusa dokonuje się również w człowieku zmartwychwstanie i odrodzenie. Eucharystia sprawia, że rodzi się w nim nowy człowiek, ukształtowany na podobieństwo Chrystusa. Jeżeli wiara jest przylgnięciem do osoby Jezusa, to przyjęcie Chrystusa i przylgnięcie do Niego znajduje najpełniejszy wyraz w Eucharystii, która jest kulminacją aktu wiary ${ }^{21}$.

Święty Jan Paweł II podkreślał, że Eucharystia jest źródłem i szczytem całego życia chrześcijańskiego. Urzeczywistnia ona komunię życia ze Stwórcą i jedność Ludu Bożego. Ukazuje przy tym najwyższy punkt Bożego działania przez który Bóg w Chrystusie uświęca świat ${ }^{22}$. Jest także miejscem najwyższego kultu, jaki ludzie w Duchu Świętym oddają Chrystusowi a przez Niego Ojcu (por. KKK 1324-1325). Stąd też wierni odnawiają w Eucharystii swą pierwszą żarliwość, umacniają się w postanowieniach, oczyszczają umysł i serce, odnajdują wewnętrzny pokój oraz ugruntowują swoją przynależność do Kościoła ${ }^{23}$. Eucharystia zdejmuje z ludzkiej eg-

${ }^{20}$ Jan Paweł II, Bulla ogłaszająca Jubileusz 1950-lecia Odkupienia Aperite portas Redemptori (6.01.1983), OsRomPol 4 (1983) 1, s. 3; tenże, Przemówienie podczas audiencji generalnej (5.05.1993), OsRomPol 14 (1993) 7, s. 42; tenże, Homilia podczas Mszy świętej połaczona $z$ udzielaniem sakramentu bierzmowania (Turyn, 2.09.1988), OsRomPol 9 (1988) 9, s. 22; Ch. Söchnborn, Krótkie wprowadzenie do czterech części Katechizmu, w: Wprowadzenie do Katechizmu Kościoła Katolickiego, red. A. Sujka, Warszawa 1994, s. 47.

${ }^{21}$ Jan Paweł II, Przemówienie wygłoszone na otwarcie obrad IV Konferencji Ogólnej Episkopatu Ameryki Łacińskiej (12.10.1992), OsRomPol 13 (1992) 12, s. 25; Kongregacja do spraw Duchowieństwa, Kapłan głosiciel słowa, szafarz sakramentów i przewodnik wspólnoty w drodze do trzeciego tysiąclecia chrześcijaństwa, Tarnów 1999, s. 43-47.

22 Jan Paweł II, Przemówienie podczas spotkania z biskupami Republiki Federalnej Niemiec (14.11.1989), OsRomPol 10 (1989) 10-11, s. 24.

23 Jan Paweł II, Przemówienie podczas audiencji generalnej (8.04.1992), OsRomPol 13 (1992) 6, s. 38-39. 
zystencji znamię przemijalności i umieszcza w niej zalążek życia wiecznego. To w niej wierni otrzymują duchową moc zdolną przeciwstawić się trudnościom i pokusom tego świata, aby zachować wierność Chrystusowi. Przyjmowana Komunia święta pogłębia zjednoczenie z Chrystusem, podtrzymuje i odnawia życie łaski otrzymanej na chrzcie świętym. Poprzez udział w Eucharystii jej uczestnicy umacniają się duchowo i pogłębiają jedność między sobą i z Bogiem. Przede wszystkim jednak Eucharystia podtrzymuje ich i chroni przed upadkami oraz umacnia w toczonej walce $z$ pokusami i słabościami ${ }^{24}$.

Zatroskanie Boga o człowieka nie zna granic. Stąd też chrześcijanin, który porzucił wiarę czy zbłądził, wybierając grzech i oddalając się od Boga, ma zawsze możność powrotu i odrodzenia przez świadomy udział w sakramencie pokuty i pojednania. Dzięki temu sakramentowi ochrzczony może bowiem odnowić i pogłębić swoją wiarę. Proces odrodzenia wymaga jednak wewnętrznego otwarcia się na wielkość i majestat Boga. W sakramencie pokuty i pojednania dochodzi do niezwykłego spotkania z Bogiem, Jego nieskończoną łagodnością i dobrocią. Przede wszystkim zostaje w nim ponownie nawiązana więź zerwana przez grzech, którego skutkiem jest odejście od Boga. Grzesznik, wyznający swój grzech, staje się na powrót „chrześcijaninem”. Sakrament pokuty jest darem przebaczenia i darem Kościoła, który otrzymuje człowiek od Boga. Dzięki pojednaniu sakramentalnemu człowiek rodzi się na nowo do życia w Bogu oraz uczestniczy w radości uwolnienia od grzechu mocą Chrystusowego przebaczenia (KKK 1422) 25 .

Zaznaczyć trzeba, że czasami w życiu człowieka grzesznego konieczny jest dłuższy okres czasu na pojednanie. Ważną rolę w sprawowaniu sakramentu pokuty i pojednania odgrywa postawa szafarza, który powinien zachęcić grzesznika do stanięcia w prawdzie przed Bogiem ${ }^{26}$. Papież Franciszek uwrażliwiał więc kapłanów wskazując im, że konfesjo-

24 Tamże, s. 39; R. Kamiński, Budowanie wspólnoty parafialnej przez Eucharystię, „Roczniki Teologiczne” 41 (1994) 6, s. 8; Franciszek, Przemówienie podczas modlitwy Anioł Pański (6.06.2021), w: https://papiez.wiara.pl/doc/6911166.Eucharystia-jest-Chlebem-grzesznikow (data dostępu: 21.08.2021).

25 Zob. Benedykt XVI, Przemówienie do uczestników kursu dla spowiedników (9.03.2012); Franciszek, Przemówienie podczas spotkania z kapłanami diecezji rzymskiej.

${ }^{26}$ Zob. Kongregacja ds. Duchowieństwa, Kapłan - szafarz miłosierdzia Bożego. Pomoce dla spowiedników i kierowników duchowych, Tarnów 2011. 
nał jest miejscem „miłosierdzia Pana”, a nie „salą tortur”. W sakramencie pokuty i pojednania powinna dotrzeć do penitenta pociecha oraz impuls zbawczej miłości Boga, działającej tajemniczo w każdym człowieku, niezależnie od jego ułomności i upadków (EG 44). Spowiednik poprzez odpowiednie słowo powinien dodawać penitentowi otuchy i odwagi, aby ten $\mathrm{w}$ atmosferze pełnego zaufania stanął w prawdzie i otworzył się na Boże miłosierdzie ${ }^{27}$.

Dzieło uzdrowienia i zbawienia kontynuowane jest w Kościele nie tylko przez sprawowanie sakramentu pokuty i pojednania, lecz także przez sakrament namaszczenia chorych, który udziela wyznawcom Chrystusa specjalnej łaski, kiedy ten doświadcza trudności i cierpień, związanych ze stanem ciężkiej choroby, starości czy bliskiej śmierci. W sakramencie tym również ma miejsce przebaczenie grzechów, o ile chory nie mógł go otrzymać poprzez sakrament pokuty. Skutkiem sakramentu może być również powrót do zdrowia, jeśli służyć on będzie dobru duchowemu chorego bądź umocnienie go na przejście do życia wiecznego (KKK 1527-1528; 1532).

Wśród innych form niosących pomoc na drodze porzucania grzechu wymienić trzeba modlitwę a zwłaszcza modlitwę wstawienniczą. Modlitwa odgrywa bowiem w życiu religijnym człowieka pierwszorzędną rolę, a zarazem stanowi o jego wewnętrznej sile. Stąd też modlitwa jest niezbędna dla osiągnięcia wszelkiego dobra duchowego i pozostaje ona w bardzo ścisłym związku z rzeczywistością wiary, jest bowiem spotkaniem człowieka z Bogiem w wierze, czyli jest postacią urzeczywistniania

${ }^{27}$ Franciszek, Przemówienie podczas spotkania z kapłanami diecezji rzymskiej; zob. Benedykt XV, Przemówienie do uczestników kursu zorganizowanego przez Penitencjarię Apostolską (11.03.2010), OsRomPol 31 (2010) 5, s. 34; człowiek, który nie chce oddać Chrystusowi swoich grzechów w sakramencie pokuty, pozostaje z nimi, żyje nimi na co dzień i oddziałuje na innych. Bóg jednak pragnie wypełnić serce człowieka darem swego Ducha, jednak niczego nie czyni na siłę, szanując wolność istoty przez siebie stworzonej. Do obiektywnych trudności stających na drodze przystąpienia do sakramentu pokuty i pojednania zaliczyć należy: zanik poczucia grzechu i winy; mentalność hedonistyczną i relatywistyczną; brak wiary w miłość Bożą; zapatrzenie w siebie i w sobie samym poszukiwanie ratunku; pobłażliwość i usprawiedliwianie swoich grzechów; tendencję do wyolbrzymiana grzechów cudzych, a pomniejszenia własnych; zaciekłą obronę ludzi, którzy popełnili znane powszechnie zło; ucieczkę w uzależnienia i przekonanie penitenta, że nie jest on w stanie się zmienić. W. Przygoda, Komunikacja pastoralna w posłudze sakramentu pokuty i pojednania, „Warszawskie Studia Pastoralne” 12 (2017), nr specjalny, s. 32-33. 
się wiary ${ }^{28}$. Modlitwa w swej istocie jest łaską i darem Bożym, a przede wszystkim ważnym źródłem rozbudzania, ożywiania i pogłębiania duchowości chrześcijańskiej. Dzięki modlitwie do Ducha Świętego człowiek żyje według Bożego zamysłu, unikając okazji do złego i dając świadectwo wierności Panu Bogu ${ }^{29}$.

Chrześcijanin powinien przyjmować na modlitwie postawę dziecka wobec Ojca, gdyż dopiero taka postawa, w świetle wiary, pozwala nawiązać autentyczny dialog z Bogiem, który jest fundamentem chrześcijańskiej modlitwy. Bóg w swej dobroci nie zawsze udziela natychmiast człowiekowi tego, o co on prosi na modlitwie, nie oznacza to jednak, że Bóg nie chce udzielić dobra, o które człowiek błaga. Przez wytrwałość w modlitwie człowiek wierzący uświadamia sobie, jak bardzo jest zależny od Boga i jak wiele od Niego otrzymuje. Szczególną formą modlitwy jest modlitwa wstawiennicza, zwłaszcza, gdy zawiera ona prośbę o łaskę nawrócenia i przemianę serca dla człowieka potrzebującego pomocy. Przykładem takiej modlitwy wstawienniczej przynoszącej łaskę nawrócenia dla swojego syna jest modlitwa matki św. Moniki za ukochanego syna Augustyna ${ }^{30}$.

Również świadectwo życia chrześcijańskiego stanowi pomoc dla ludzi grzesznych i przyczynia się do porzucenia przez nich grzesznej drogi, ponieważ świadkowie wiary ukazują swoim życiem autentyczne oblicze Chrystusa i Jego Kościoła. Świadectwo osoby wiernej Ewangelii przynagla wątpiących do refleksji nad drogą wiary, zagubionym ukazuje światło nadziei, a wszystkim pozostałym przypomina drogę do Boga i ją wskazuje. Według nauczania Kościoła pełni ono w swej istocie funkcję zbawczą, gdyż kształtuje wspólnotę eklezjalną i jest środkiem zbawienia dla świadczących, jak i dla tych, którym zostało dane (EA 55). Świadectwo złożone Prawdzie przez Chrystusa przyniosło światu odkupienie (RH 7-8). Natomiast świadectwo chrześcijańskie składane wobec świata oddziałuje

${ }_{28}$ S. Urbański, Wiara $w$ modlitwie chrześcijańskiej, w: Wiara w postawie ludzkiej, red. W. Słomka, Lublin 1991, s. 247.

29 Zob. S. Kulpaczyński, Rola katechety w wychowaniu do modlitwy, „Roczniki Teologiczno-Katechetyczne” 36 (1989) 6, s. 117; F. Woronowski, Zarys teologii pastoralnej, t. 1, Warszawa 1984, s. 335.

30 Jan Paweł II, Przemówienie podczas audiencji generalnej (16.09.1992), OsRomPol 13 (1992) 11, s. 20; tenże, Przemówienie podczas audiencji dla uczestników III Międzynarodowej Konferencji Kapelanów Wojskowych (6.02.1992), OsRomPol 13 (1992) 7, s. 32-33; zob. Św. Augustyn, Wyznania, tł. Z. Kubiak, Kraków 2009, s. 265. 
szczególnie na tych, którzy jeszcze nie przyjęli Ewangelii, którzy uwierzyli i przeżywają radość z udziału w jedności z Chrystusem, jest ono wreszcie czytelnym znakiem dla ludzi którzy się pogubili i potrzebują wsparcia. Świadczenie wartościom nadprzyrodzonym pomaga bowiem odnaleźć prawdę o Bogu i drogę do Niego. Dlatego przykład życia współczesnych chrześcijan ma ogromne znaczenie w pokonywaniu ludzkich słabości. Należy przy tym pamiętać, że postawa autentycznego świadka jest zawsze owocem jego osobistej świętości. Dlatego też istotną przeszkodą w przyjęciu przez chrześcijan misji świadectwa jest brak świętości świadka ${ }^{31}$.

Wśród form odgrywającą ważną rolę w procesie niesienia pomocy człowiekowi grzesznemu trudno nie dostrzec roli duszpasterstwa indywidualnego a szczególnie braterskich spotkań ${ }^{32}$. To właśnie w trakcie spotkania indywidualnego uwaga skupiona jest na konkretnej osobie, z jej indywidualnością i niepowtarzalną drogą do Boga, podczas gdy w dużej zbiorowości istnieje niebezpieczeństwo zgubienia z oczu konkretnego wiernego z jego indywidualnością. Chrześcijanin choć obiektywnie pozostaje w centrum zainteresowania zbawczego pośrednictwa Kościoła, subiektywnie jednak może czuć się pominięty i opuszczony, samotny, pozostający ze swoimi problemami. Stąd też owe spotkania indywidualne nabierają znaczenia zwłaszcza w życiu tych wszystkich, którzy pragną takiego spotkania i pomocy. Spotkania indywidualne i w małych grupach przyczyniają się do wychodzenia $\mathrm{z}$ anonimowości i doceniają konkretnego człowieka $\mathrm{z}$ jego indywidualnością. W tym kontekście trzeba ko-

31 RM 42; Jan Paweł II, Homilia podczas Mszy św. (Lecce, 18.09.1994), OsRomPol 15 (1994) 11, s. 29; zob. J. Salij, Świadectwo wiary jako odpowiedź na współczesne jej zakwestionowanie, „Ateneum Kapłańskie” 65 (1973) 386, s. 390-391; S. Mojek, Wartość świadectwa wiary w dziele ewangelizacji, „Roczniki Teologiczne” 41 (1994) 3, s. 92; K. Rahner, O możliwości wiary dzisiaj, Kraków 1965, s. 252.

32 W Nowym Testamencie mamy ukazane spotkania Chrystusa z konkretnym człowiekiem i jego niepowtarzalnymi problemami. Wymienić tu można: chociażby rozmowę Chrystusa z Nikodemem, Zacheuszem, samarytanką, Szymonem Faryzeuszem, kobietą cudzołożną czy bogatym młodzieńcem, rozmowę z uczniami na osobności, spotkanie w drodze do Emaus, dialog z Piotrem bądź też spotkania z człowiekiem cierpiącym i jego uzdrowienie. Owe biblijne obrazy stanowią wzór dla duszpasterstwa indywidualnego. Uzasadnienie dla tego rodzaju posługi znajdujemy również w dokumentach Kościoła, a zwłaszcza w adhortacji apostolskiej Pawła VI Evangelii nuntiandii, gdzie podkreślona jest rola osobistego kontaktu w duszpasterstwie (EN 46) czy w adhortacji papieża Franciszka Evangelii gaudium, podkreślającej znaczenie ewangelizacji od osoby do osoby, rozmowy indywidualnej i dialogu (EG 127-134). 
niecznie docenić duszpasterstwo indywidualne, które stara się docierać do wiernych, umożliwiając im odkrycie przed duszpasterzem lub doradcą własnej sytuacji i uzyskanie wsparcia duchowego. W spotkaniu tym istotną i pomocną rolę odgrywa rozmowa pastoralna, ukierunkowana na wartości duchowe i religijne ${ }^{33}$.

\section{PODSUMOWANIE}

W podsumowaniu zaznaczyć trzeba, że prawdziwe wyzwolenie z grzechu pojawia się dopiero wtedy, gdy zainteresowany grzesznik otworzy się na Pana Boga, gdy uzna swoje winy, wyzna je i odprawi pokutę, gdyż tylko wtedy dostąpi Bożego miłosierdzia. Wyjaśnić również należy, że miłosierdzie Boże nie jest „bezdusznym płaszczem”, który bezwładnie spada na grzesznika z nieba. Miłosierdzie może być okazane tylko podczas osobowego spotkania miłosiernego Boga z uniżonym grzesznikiem. Biblijna przypowieść o miłosiernym ojcu wskazuje bardzo wyraźnie na inicjatywę i czyn syna marnotrawnego, który doświadczając nędzy egzystencjalnej podjął decyzję, mówiąc, ,zabiorę się i pójdę do mego Ojca i powiem mu: Ojcze zgrzeszyłem przeciw Bogu i względem Ciebie" (Łk 15, 16). Przypowieść ta pokazuje, że, to nie ojciec wyszedł z inicjatywą, by cokolwiek zmienić w życiu syna. Biblijny ojciec cierpliwie czekał na powrót syna. Bez tego powrotu miłosierdzie ojca nie zdałoby się na nic synowi. Przypowieść ewidentnie wskazuje, jak ważna jest decyzja grzesznika o potrzebie nawrócenia i jego osobiste zaangażowanie w tenże proces. Samo więc przekonanie o nieskończonym i bezwarunkowym miłosierdziu Boga bez nawrócenia nic nie zmienia w życiu grzesznika. Chcąc dostąpić łaski miłosierdzia trzeba wyznać swój grzech i wejść na drogę nawrócenia. W procesie tym człowiekowi grzesznemu niesie pomoc Kościół i osoby do niego należące poprzez miłosierne towarzyszenie.

33 A. Tomkiewicz, Rozmowa pastoralna, s. 749-751. 


\section{BIBLIOGRAFIA}

Paweł VI, Adhortacja Apostolska Evangelii nuntiandi o ewangelizacji w świecie współczesnym $(8,12.1975)$.

Jan Paweł II, Adhortacja apostolska o Jezusie Chrystusie, który żyje w Kościele, jako źródło nadziei dla Europy Ecclesia in Europa (28.06.2003).

Jan Paweł II, Bulla ogłaszająca Jubileusz 1950-lecia Odkupienia Aperite portas Redemptori (6.01.1983).

Jan Paweł II, Encyklika Veritatis splendor o niektórych podstawowych problemach nauczania moralnego Kościoła (6.08.1993).

Jan Paweł II, Homilia podczas Mszy świętej połaczona z udzielaniem sakramentu bierzmowania (Turyn, 2 IX 1988), OsRomPol 9 (1988) 9, s. 22.

Jan Paweł II, Homilia podczas Mszy św. (Lecce, 18 IX 1994), OsRomPol 15 (1994) 11, s. 29.

Jan Paweł II, Homilia podczas Mszy św. (San Salwador, 8 II 1996), OsRomPol 17 (1996) 5, s. 27.

Jan Paweł, Przemówienie podczas audiencji generalnej (1 III 1983), OsRomPol 4 (1983) 3, s. 18.

Jan Paweł II, Przemówienie podczas audiencji generalnej (2 X 1985), OsRomPol 6 (1985) 10-12, s. 19.

Jan Paweł II, Przemówienie podczas audiencji generalnej (5 III 1986), OsRomPol 7 (1986) 3, s. 10.

Jan Paweł II, Przemówienie do uczestników Międzynarodowego Kongresu Teologii Moralnej (10 IV 1986), OsRomPol 7 (1986) 5, s. 10.

Jan Paweł II, Przemówienie na spotkaniu z Konferencja Episkopatu Austrii (Salzburg, 24 VI 1988), OsRomPol 9 (1988) 7, s. 24-26.

Jan Paweł II, Przemówienie podczas spotkania z biskupami Republiki Federalnej Niemiec (14 XI 1989), OsRomPol 10 (1989) 10-11, s. 1-26.

Jan Paweł II, Przemówienie podczas audiencji dla uczestników III Międzynarodowej Konferencji Kapelanów Wojskowych (6.02.1992), OsRomPol 13 (1992) 7, s. 32-33.

Jan Paweł II, Przemówienie podczas audiencji generalnej (8.04.1992), OsRomPol 13 (1992) 6, s. 38-39.

Jan Paweł II, Przemówienie podczas audiencji generalnej (16.09.1992), OsRomPol 13 (1992) 11, s. 20.

Jan Paweł II, Przemówienie wygłoszone na otwarcie obrad IV Konferencji Ogólnej Episkopatu Ameryki Łacińskiej (12.10.1992), OsRomPol 13 (1992) 12, s. 22-31.

Jan Paweł II, Przemówienie podczas audiencji generalnej (5.05.1993), OsRomPol 14 (1993) 7, s. 42.

Benedykt XV, Przemówienie do uczestników kursu zorganizowanego przez Penitencjarię Apostolskg̨ (11.03.2010), OsRomPol 31 (2010) 5, s. 34.

Benedykt XVI, Przemówienie do uczestników kursu dla spowiedników (9.03.2012), w: https://opoka.org.pl/biblioteka/W/WP/benedykt_xvi/przemowienia/spowiednicy_09032012.html (data dostępu: 20.08.2021). 
Benedykt XVI, Przemówienie do uczestników Zgromadzenia Ogólnego Konferencji Episkopatu Włoch (24.05.2012), w: https://opoka.org.pl/biblioteka/W/WP/benedykt_ xvi/przemowienia/ep-it_24052012.html (data dostępu: 20.05.2021).

Franciszek, Adhortacja apostolska o głoszeniu Ewangelii w dzisiejszym świecie Evangelii gaudium (24.11.2013).

Franciszek, Bulla o nadzwyczajnym jubileuszu miłosierdzia Misericordie Vultus (11.04.2015).

Franciszek, Bóg jest młody. Rozmowa z Thomasem Leoncinim, Kraków 2018.

Franciszek, Przemówienie podczas modlitwy Anioł Pański (6.06.2021), w: https://papiez. wiara.pl/doc/6911166.Eucharystia-jest-Chlebem-grzesznikow (data dostępu: 21.08.2021).

Franciszek, Przemówienie podczas spotkania z kapłanami diecezji rzymskiej (6.03.2014), w: https://opoka.org.pl/biblioteka/W/WP/franciszek_i/przemowienia/kaplani_06032014.html (21.08.2021).

Draguła A., O szpitalu polowym papieża Franciszka, w: https://wiez.pl/2015/10/30/o-szpitalu-polowym-papieza-franciszka/ (data dostępu: 21.08.2021).

Flader M., Formacja chrześcijańska młodzieży w mediach społecznościowych. Studium teologicznopastoralne na podstawie badań maturzystów $w$ archidiecezji przemyskiej, praca doktorska (archiwum mps UMK) Toruń 2020.

Kamiński R., Budowanie wspólnoty parafialnej przez Eucharystię, „Roczniki Teologiczne” 41 (1994) 6, s. 5-14.

Kongregacja do spraw Duchowieństwa, Kapłan głosiciel słowa, szafarz sakramentów i przewodnik wspólnoty $w$ drodze do trzeciego tysiąclecia chrześcijaństwa, Tarnów 1999.

Kongregacja ds. Duchowieństwa, Kapłan - szafarz miłosierdzia Bożego. Pomoce dla spowiedników i kierowników duchowych, Tarnów 2011.

Kudasiewicz J., Miłosierdzie w Ewangeliach, w: Jan Pawet II. Dives in Misericordia. Tekst $i$ komentarze, red. S. Nagy, Lublin 1983, s. 62-82.

Kulpaczyński S., Rola katechety w wychowaniu do modlitwy, „Roczniki Teologiczno-Katechetyczne" 36 (1989) 6, s. 117-127.

Mariański J., Praktyki religijne $w$ Polsce $w$ procesie przemian, w: Postawy społeczno-religijne Polaków 1991-2012, red. L. Adamczuk E. Firlit, W. Zdaniewicz, Warszawa 2013, s. 59-101.

Mojek S., Kościół jako sakrament we wspólnocie ludzkiej, „Roczniki Teologiczne” 40 (1993) 3, s. 10-30.

Mojek S., Wartość świadectwa wiary $w$ dziele ewangelizacji, „Roczniki Teologiczne” 41 (1994) 3, s. 82-93.

Nossol A., Teologia bliższa życia, Opole 1984.

Pawlina K., Polska młodzież przełomu wieków, Warszawa 1998.

Pikor W., Biblijne pytania o Boże Miłosierdzie, Pelplin 2016.

Przygoda W., Komunikacja pastoralna w posłudze sakramentu pokuty i pojednania, „Warszawskie Studia Pastoralne” 12 (2017), nr specjalny, s. 29-51.

Rahner K., O możliwości wiary dzisiaj, Kraków 1965. 
Salij J., Świadectwo wiary jako odpowiedź na współczesne jej zakwestionowanie, „Ateneum Kapłańskie” 65 (1973) 386, s. 390-402.

Söchnborn Ch., Krótkie wprowadzenie do czterech części Katechizmu, w: Wprowadzenie do Katechizmu Kościoła Katolickiego, red. A. Sujka, Warszawa 1994, s. 36-56.

Strzelczyk G., Kościół niełatwa miłość, Kraków 2017.

Św. Augustyn, Wyznania, tł. Z. Kubiak, Kraków 2009.

Tomkiewicz A., Rozmowa pastoralna, w: Leksykon teologii pastoralnej, red. R. Kamiński, W. Przygoda, M. Fiałkowski, Lublin 2006, s. 749-752.

Urbański S., Wiara $w$ modlitwie chrześcijańskiej, w: Wiara w postawie ludzkiej, red. W. Słomka, Lublin 1991, s. 239-254. 
